\title{
Kemampuan Pemahaman Konsep Matematika Siswa melalui Model Learning Cycle $7 E$ pada Mata Pelajaran Matematika di Kelas XI IPS SMA N 1 Sungai Pua Tahun Pelajaran 2018/2019
}

\author{
Refina Oktavianda ${ }^{1}$, Muhiddinur Kamal ${ }^{2}$, dan Haida Fitri ${ }^{3}$ \\ ${ }_{1,2,3}$ Program studi pendidikan matematika, LAIN Bukittinggi \\ e-mail: refinaoktavianda2@gmail.com
}

\begin{abstract}
ABSTRAK. Penelitian ini bertujuan untuk mengetahui apakah kemampuan pemahaman konsep matematika siswa yang mengikuti pembelajaran dengan model Learning Cycle 7E lebih baik daripada pembelajaran konvensional di kelas XI IPS SMA N 1 Sungai Pua Tahun Pelajaran 2018/2019. Jenis penelitian ini adalah pra eksperimen dengan rancangan The Static Group Comparison Design. Populasi dalam penelitian ini adalah seluruh kelas XI IPS. Sampel dalam penelitian ini adalah siswa kelas XI IPS 2 sebagai kelas eksperimen dan kelas XI IPS 1 sebagai kelas kontrol. Teknik pengumpulan data pada penelitian ini menggunakan tekni tes dengan instrument soal tes kemampuan pemahaman konsep matematika. Uji coba dilakukan di kelas XI IPS 4 SMA N 1 Sungai Pua. Hasil penelitian menunjukkan bahwa kemampuan pemahaman konsep matematika siswa yang mengikuti pembelajaran dengan model Learning Cycle 7E lebih baik daripada pembelajaran konvensional di kelas XI IPS SMA N 1 Sungai Pua tahun pelajaran 2018/2019.
\end{abstract}

Kata kunci: model learning cycle 7 E, kemampuan pemahaman konsep matematika.

\section{PENDAHULUAN}

Tujuan mata pelajaran matematika menurut Permendikbud 58 tahun 2014 adalah agar siswa mampu memahami konsep matematika, menjelaskan keterkaitan antar konsep dan mengaplikasikan konsep atau algoritma secara luwes, akurat, efesien dan tepat dalam pemecahan masalah. (permendikbud No. 58, 2014). Kemampuan pemahaman konsep merupakan salah satu kemampuan yang harus dimiliki dan dibangun siswa. Menurut Suherman, kemampuan pemahaman konsep merupakan bagian yang paling penting dalam pembelajaran matematika, karena konsep-konsep dalam matematika terorganisir secara sistematis, logis, hirarkis dari yang paling sederhana ke yang paling komplek (Suherman, 2003). Berdasarkan peraturan Dirjen Dikdasmen Depdiknas nomor 506/C/PP/2004 tanggal 11 November 2004 (Mawaddah, 2016)diuraikan bahwa indikator siswa memahami konsep matematika adalah:

1. Menyatakan ulang sebuah konsep

2. Mengklasifikasi objek menurut sifat-sifat tertentu sesuai dengan konsepnya.

3. Memberi contoh dan non contoh dari konsep.

4. Menyajikan konsep dalam berbagai bentuk representasi matematis.

5. Mengembangkan syarat perlu atau syarat cukup suatu proses.

6. Menggunakan, memanfaatkan, dan memilih prosedur atau operasi tertentu.

7. Mengaplikasikan konsep atau algoritma pemecahan masalah.

Guru harus berupaya untuk melibatkan siswa dalam proses pembelajaran, sehingga siswa bisa menyusun pengetahuannya sendiri dan guru berperan sebagai fasilitator dan pembimbing. Semakin besar keterlibatan siswa dalam proses pembelajaran maka akan semakin besar peluang siswa memahami konsep pelajaran yang diberikan. 
Berdasarkan hasil observasi yang peneliti lakukan di SMA N 1 Sungai Pua pada tanggal 10 Juli 2018, diketahui bahwa sekolah ini menerapkan kurikulum 2013. Namun, fakta yang ditemukan di dalam kelas khususnya kelas XI, proses pembelajaran masih menggunakan pembelajaran konvensional yaitu pembelajaran yang terpusat kepada guru (teachercentered). Dimana guru menjelaskan materi di depan kelas, memberikan beberapa contoh soal, kemudian memberikan beberapa soal latihan dan diakhir pertemuan mengadakan kuis.

Berdasarkan perolehan data persentase ketuntasan nilai ulangan harian 2 Semester Ganjil siswa kelas XI SMA N 1 Sungai Pua Tahun Pelajaran 2018/2019 ditemukan bahwa mayoritas siswa kelas XI IPA memperoleh nilai lebih dari 75, yaitu berada di atas Kriteria Ketuntasan Minimal (KKM), sedangkan perolehan nilai siswa kelas XI IPS masih di bawah kriteria KKM.Kelas XI IPS hanya mampu memperoleh presentase ketuntasan sebesar 9,52\% $19,05 \%$, artinya hanya 2 sampai dengan 4 orang yang mampu memperoleh nilai yang tuntas.

Dengan adanya perbedaan hasil belajar siswa kelas XI SMA Negeri 1 Sungai Pua tersebut, peneliti menduga bahwa hal ini disebabkan oleh penerapan pembelajaran yang berbeda di dalam kelas. Dengan demikian, peneliti tertarik untuk melakukan observasi dan wawancara lebih mendalam di kelas XI IPS SMA N 1 Sungai Pua untuk mengetahui penyebab masih rendahnya nilai ulangan harian siswa.

Berdasarkan hasil observasi pada tanggal 14 juli 2018 di kelas XI IPS 1 dan XI IPS 3 SMA N 1 Sungai Pua ditemukan bahwa rendahnya partisipasi siswa dalam proses pembelajaran, kurangnya inisiatif untuk mencatat materi yang diajarkan dan ketika diajukan pertanyaan hanya sedikit dari mereka yang merespon pertanyaan tersebut. Pada saat diberikan tugas, mereka lebih cendrung mengandalkan siswa lainnya. Sehingga ketika diberikan soal yang berbeda dari contoh yang diberikan, selain tidak menguasai konsep dasar pembelajaran mereka juga tidak dapat menuntaskannya disebabkan oleh faktor malu bertanya dan terbatasnya waktu yang diberikan.

Hasil observasi tersebut didukung oleh hasil wawancara dengan guru mata pelajaran matematika kelas XI SMA N 1 Sungai Pua. Kendala yang dihadapi saat mengajar di kelas XI IPS terdapat pada proses pembelajaran, siswa cenderung pasif dan sebagian dari mereka sungkan untuk bertanya kepada guru jika mengalami kesulitan dalam memahami materi. Ketika diberikan latihan siswa menjawabnya karena kurang memahami konsepnya. Disamping itu, angka kehadiran siswa dikelas XI IPS masih rendah. Sehingga pada pertemuan berikutnya saat guru menjelaskan materi yang masih terkait dengan pertemuan sebelumnya, kebanyakan dari mereka lupa dengan materi pada pertemuan sebelumnya. Kendala lain yang dihadapi guru adalah kurangnya waktu untuk memberikan lebih banyak variasi soal.

Setelah dilakukan analisis pada soal Ulangan Harian 2 Semester Ganjil siswa, lima soal yang diujikan secara keseluruhan merupakan soal yang berkaitan dengan kemampuan pemahaman konsep matematika. Hasil persentase kemampuan pemahaman konsep matematika siswa kelas XI IPS SMA N 1 Sungai Pua Tahun Pelajaran 2018/2019, dalam hal ini peneliti menilai menggunakan rubrik penskoran kemampuan pemahaman konsep matematika siswa. Peneliti juga menggelompokkan persentase kemampuan pemahaman konsep matematika siswa berdasarkan kategori persentase kemampuan pemahaman konsep matematika menurut Ningsih (Mawaddah, 2016) dimana peneliti mengelompokkan dalam kategori cukup. Seperti disajikan pada tabel di bawah ini:

\section{Tabel 1. Interpretasi Nilai Kemampuan Pemahaman Konsep}

\begin{tabular}{ccc}
\hline No. & Nilai & Kriteria \\
\hline 1. & $85,00-100$ & SangatBaik \\
2. & $70,00-84,99$ & Baik \\
3. & $55,00-69,99$ & Cukup \\
4. & $40,00-54,99$ & Rendah \\
5. & $0,00-39,99$ & SangatRendah \\
\hline
\end{tabular}


Berikut adalah tabel persentase kemampuan pemahaman konsep matematika ulangan harian 2 semester ganjil siswa kelas XI IPS SMA N 1 Sungai Pua Tahun Pelajaran 2018/2019 dengan 5 soal kemampuan pemahaman konsep matematika:

\section{Tabel 2. Persentase Kemampuan Pemahaman Konsep Matematika Ulangan Harian 2 Semester Ganjil Siswa Kelas XI IPS SMA N 1 Sungai Pua Tahun Pelajaran 2018/2019}

\begin{tabular}{ccccccc}
\hline \multirow{2}{*}{ Kelas } & \multicolumn{2}{c}{ Jumlah } & \multicolumn{2}{c}{ Penilaian } & \multicolumn{2}{c}{ Persentase } \\
\cline { 2 - 7 } & Soal & Siswa & $\geq \mathbf{5 5}$ & $<\mathbf{5 5}$ & $\mathbf{( \% )}$ & $\mathbf{( \% )}$ \\
\hline XI IPS 1 & 5 & 21 & 8 & 13 & 38,10 & 61,90 \\
XI IPS 2 & 5 & 22 & 9 & 13 & 40,91 & 59,09 \\
XI IPS 3 & 5 & 21 & 10 & 11 & 47,62 & 52,38 \\
XI IPS 4 & 5 & 21 & 7 & 14 & 33,33 & 66,67 \\
\hline
\end{tabular}

Sumber: Nilai UH 2 semester genap kelas XI IPS SMA N 1 Sungai Pua

Dari tabel 2 terlihat bahwa rata-rata jawaban siswa pada ulangan harian 2 semester ganjil dengan soal kemampuan pemahaman konsep matematika berada dibawah angka 55, dimana persentase kemampuan pemahaman konsep matematika siswa dibawah 55 berkisar 52,38\% sampai $66,67 \%$. Hal ini menunjukkan bahwa masih rendahnya kemampuan pemahaman konsep matematika siswa, sehingga mereka mengalami kesulitan dalam menjawab soal.

Untuk mengatasi rendahnya kemampuan pemahaman konsep matematika siswa maka diperlukan suatu pembelajaran yang menuntut siswa dapat membangun dan mengembangkan pemahamannya sendiri. Salah satu pembelajaran matematika yang diharapkan dapat meningkatkan kemampuan pemahaman konsep matematika siswa di sekolah adalah pembelajaran dengan model Learning Cycle 7E.

Menurut Eisenkraft hakikat model Learning Cycle $7 E$ adalah model pembelajaran yang berbasis konstruktivisme yang terdiri dari tujuh fase belajar dan bertujuan untuk menekankan pentingnya memunculkan pemahaman awal siswa dan memperluas (transfer) konsep (Adillah, 2015). Berdasarkan hal tesebut maka proses pembelajaran bukan lagi sekedar transfer pengetahuan dari guru ke siswa tetapi merupakan proses penerimaan konsep yang berorientasi pada keterlibatan siswa secara aktif, proses pembelajaran seperti ini yang akan mudah diingat siswa.

Model Learning Cycle 7E (pembelajaran bersiklus), yaitu suatu modelpembelajaran yang berpusat pada siswa (student centered) (Shoimin, 2014). Model Learning Cycle 7E patut diterapkan karena termasuk pembelajaran yang berbasis kontruktivisme (Ngalimun, 2013). Berdasarkan pandangan konstruktivisme menurut Slavin anak secara aktif membangun pengetahuan dengan cara terus menerus mengasimilasi dan mengakomodasi informasi baru, dengan demikian konstruktivisme merupakan teori yang menekankan peran aktif siswa dalam membangun pemahaman mereka tentang realita melalui perkembangan kognitif (Adilah, 2015).

Fase-fase model Learning Cycle $7 E$ menurut Eisenkraft (Sadia, 2014)adalah sebagai berikut:

1) Elicit

Pada fase ini, guru melakukan pengungkapan terhadap pengetahuan awal (prior knowledge) siswa dengan jalan mengajukan pertanyaan-pertanyaan yang berkaitan dengan materi yang akan dipelajari. Sedangkan siswa menyampaikan jawaban atas pertanyaan yang merupakan gagasan atau ide awal siswa. Pada fase ini guru dapat mengetahui profil pengetahuan awal serta miskonsepsi siswa yang tujuannya agar guru dapat menentukan strategi yang dipandang paling efektif untuk mencapai tujuan pembelajaran. 
2) Engagement

Pada fase ini, siswa dimotivasi guna membangkitkan minat dan keingintahuan siswa tetang topik yang akan dibahas. Siswa diajak untuk merumuskan prediksi-prediksi tentang fenomena yang akan dibahas dan dibuktikan dalam tahap eksplorasi.

3) Exploration

Pada fase ini, siswa diberi kesempatan untuk bekerja sama dalam kelompok kecil (4-5 orang) untuk menguji prediksi-prediksi yang telah dirumuskan pada fase engagement, dengan jalan melakukan kegiatan pratikum atau studi lapangan maupun melalui studi pustaka. Para siswa diberi kesempatan berinkuiri dengan melibatkan seluruh panca indranya untuk berinteraksi dengan lingkungan dan objek ketidakseimbangan (disekuilibrasi) dalam struktur mental siswa yang ditandai dengan munculnya berbagai pertanyaan yang mengarahkan pada berkembangnya daya nalar tingkat tinggi (high level reasoning). Dari proses inkuiri pada fase ini, masing-masing kelompok siswa diharapkan dapat merumuskan konsepsinya sebagai hasil eksplorasi yang telah dilakukan.

4) Explanation

Pada fase ini, siswa mempresentasikan hasil eksplorasinya dalam diskusi kelas. Para siswa diberi kesempatan untuk menjelaskan hasil eksplorasinya kepada siswa lainnya. Guru memberi motivasi dan mendorong siswa untuk menjelaskan konsep dan prinsip-prinsip ilmiah dengan bahasa mereka sendiri, serta meminta bukti dan klasifikasi dari penjelasan mereka. Tugas utama guru pada fase ini adalah sebagai fasilitator dan mediator pembelajaran. Para siswa diharapkan telah menemukan istilah-istilah dari konsep yang dipelajari. Pada fase ini diharapkan telah terjadi keseimbangan (ekuilibrasi) antara konsep baru yang dipelajari dengan struktur kognitif siswa.

5) Elaboration

Pada fase ini, siswa terlibat dalam diskusi dan akan timbul hal-hal yang baru terkait dengan materi pelajaran yang menjadi target pembelajaran. Pemahaman yang telah dibangun selanjutnya dikembangkan dalam diskusi kelas. Jika masih ada siswa yang mengalami miskonsepsi, guru memperbaiki miskonsepsi yang dialami siswa menuju konsepsi ilmiah. Para siswa diajak untuk menerapkan pemahaman konsepnya yang baru melalui kegiatan pemecahan masalah terhadap masalah-masalah yang nyata dalam kehidupan siswa. Penerapan konsep pada fase ini diharapkan dapat meningkatkan pemahaman konsep matematika siswa terhadap konsep yang mereka pelajari.

6) Evaluation

Pada fase ini, dilakukan evaluasi terhadap pengetahuan, pemahaman konsep, atau penguasaan kompetensi melalui kegiatan pemecahan masalah (problem solving) dalam konteks yang baru atau situasi yang baru (new situation). Melalui fase ini dapat diketahui seberapa dalam dan seberapa luas tingkat pemahaman siswa terhadap konsep-konsep yang telah dipelajarinya.

7) Extended

Pada fase ini, siswa diberi kesempatan untuk mengembangkan dan memperluas konsep-konsep ilmiah yang telah dikuasainya dalam situasi yang lebih kompleks dalam kehidupan sehari-hari. Siswa diharapkan telah mampu menjelaskan berbagai fenomena yang lebih kompleks, sehingga status pengetahuan yang telah dipahaminya berada pada status fruitfull.

Perbedaan antara model learning cycle $5 E$ dengan model learning cycle $7 E$ menurut Sadia (2014) adalah bahwa pada model learning cycle $7 E$ diawali dengan pengungkapan pengetahuan awal (prior knowledge) siswa tentang suatu topik materi pelajaran melalui pengajuan pertanyaan- 
pertanyaan oleh guru (elicit) dan diakhiri dengan pemberian kesempatan kepada siswa untuk mengembangkan dan menerapkan konsep-konsep mau pun prinsip-prinsip ilmiah yang telah dikuasainya pada situasi yang lebih kompleks dalam kehidupan sehari-hari (extend).

Keterkaitan antara kemampuan pemahaman konsep matematika siswa dengan menggunakan model learning gycle $7 E$ ini didukung juga oleh Eisenkraft, yaitu model learning cycle $7 E$ merupakan model pembelajaran yang dapat meningkatkan pemahaman siswa terhadap konsepkonsep maupun prinsip-prinsip ilmiah dari suatu materi pembelajaran.(Sadia, 2014). Prinsipprinsip ilmiah dapat juga ditemukan dalam pelajaran matematika, dengan mengaitkan materi pelajaran dengan kehidupan sehari-hari akan membuat siswa lebih memahami konsep dari materi pelajaran.

Sedangkan untuk konten pada bagian pendahuluan, harus memuat: Pertama, pemaparan topik utama penenelitian. kedua, memuat literatur terbaru terkait dengan mensitasi literatur penelitian terbaru terkait dengan artikel yang dikaji. Ketiga, harus menunjukkan kesenjangan yang belum terisi oleh penelitian/literatur, ketidakkonsistenan dan kotrovrsi yang muncul diantara literatur yang ada. Keempat, memuat permasalahan, tujuan kajian, kontek kajian, dan unit analisis yang digunakan, dan Kelima, menampilkan apa yang dibahas dalam struktur artikel.

\section{METODE}

Jenis penelitian pada penelitian ini yaitu penelitian pra-eksperimen. Rancangan penelitian ini menggunakan teknik randomized control group only design: the static group comparison design (Suryabrata, 2014). Populasi dalam penelitian ini adalah siswa kelas XI IPS SMA N 1 Sungai Pua yang terdaftar pada tahun ajaran 2018/2019. Pengambilan sampel dilakukan menggunakan teknik random sampling atau secara acak, artinya setiap populasi memiliki kesempatan yang sama untuk dipilih menjadi sampel dalam penelitian. Sampel dalam penelitian ini adalah siswa kelas XI IPS 2 dengan jumlah 21 orang siswasebagai kelas eksperimenyaitu kelas yang melaksanakan pembelajaran menggunakan model learning cycle 7E dan kelas XI IPS 1 dengan 22 orang siswa sebagai kelas kontrolyaitu kelas yang melaksanakan pembelajaran konvensional (Strategi ekspositori).

Teknik pengumpulan data pada penelitian ini menggunakan teknik tes. Instrumen (alat) pengumpulan data dalam penelitian ini adalah soal tes kemampuan pemahaman konsep matematika yang berbentuk soal essay dengan tujuan agar dapat menggambarkan kemampuan pemahaman konsep matematika siswa. Materi yang diujikan adalah materi Matriks kelas XI SMA.

Kemampuan pemahaman konsep matematika siswa dinyatakan dengan nilai melalui rubrik penskoran kemampuan pemahaman konsep matematika siswa adaptasi Kasum (Mawaddah, 2016), seperti yang terlihat pada tabel di bawah ini:

Tabel 3. Rubrik Penskoran Kemampuan Pemahaman Konsep Matematika

\begin{tabular}{clc}
\hline $\begin{array}{c}\text { Indikator Pemahaman } \\
\text { Konsep }\end{array}$ & \multicolumn{1}{c}{ Keterangan } & Skor \\
\hline $\begin{array}{c}\text { Menyatakan ulang sebuah } \\
\text { konsep }\end{array}$ & Jawaban kosong & 0 \\
& Tidak dapat menyatakan ulang konsep & 1 \\
& Dapat menyatakan ulang konsep tetapi masih banyak & 2 \\
& kesalahan & 3 \\
& Dapat menyatakan ulang konsep tetapi belum tepat & 4 \\
Memberi contoh dan non & Dapat menyatakan ulang konsep dengan tepat & 0 \\
contoh dari konsep & Tawaban kosong & 1 \\
& Dapat memberikan contoh dan bukan contoh tetapi masih & 2 \\
& banyak kesalahan & 3 \\
& Dapat memberikan contoh dan bukan contoh tetapi belum & 3 \\
& tepat
\end{tabular}




\begin{tabular}{|c|c|c|}
\hline $\begin{array}{l}\text { Indikator Pemahaman } \\
\text { Konsep }\end{array}$ & Keterangan & Skor \\
\hline \multirow{6}{*}{$\begin{array}{l}\text { Mengklasifikasi objek menurut } \\
\text { sifat-sifat tertentu sesuai } \\
\text { dengan konsepnya }\end{array}$} & Dapat memberikan contoh dan bukan contoh dengan tepat & 4 \\
\hline & Jawaban kosong & 0 \\
\hline & $\begin{array}{l}\text { Tidak dapat mengklasifikasikan objek sesuai dengan } \\
\text { konsepnya }\end{array}$ & 1 \\
\hline & $\begin{array}{l}\text { Dapat menyebutkan sifat-sifat sesuai dengan konsepnya tetapi } \\
\text { masih banyak kesalahan }\end{array}$ & 2 \\
\hline & $\begin{array}{l}\text { Dapat menyebutkan sifat-sifat sesuai dengan konsepnya tetapi } \\
\text { belum tepat }\end{array}$ & 3 \\
\hline & $\begin{array}{l}\text { Dapat menyebutkan sifat-sifat sesuai dengan konsepnya } \\
\text { dengan tepat }\end{array}$ & 4 \\
\hline \multirow{5}{*}{$\begin{array}{l}\text { Menyajikan konsep dalam } \\
\text { bentuk representasi matematis }\end{array}$} & Jawaban kosong & 0 \\
\hline & $\begin{array}{l}\text { Dapat menyajikan sebuah konsep dalam bentuk representasi } \\
\text { matematika (gambar) tetapi belum tepat dan tidak } \\
\text { menggunakan penggaris }\end{array}$ & 1 \\
\hline & $\begin{array}{l}\text { Dapat menyajikan sebuah konsep dalam bentuk representasi } \\
\text { matematika (gambar) tetapi belum tepat }\end{array}$ & 2 \\
\hline & $\begin{array}{l}\text { Dapat menyajikan sebuah konsep dalam bentuk representasi } \\
\text { matematika (gambar) tetapi tidak menggunakan penggaris }\end{array}$ & 3 \\
\hline & $\begin{array}{l}\text { Dapat menyajikan sebuah konsep dalam bentuk representasi } \\
\text { matematika (gambar) }\end{array}$ & 4 \\
\hline \multirow{5}{*}{$\begin{array}{l}\text { Mengembangkan syarat perlu } \\
\text { dan syarat cukup dari suatu } \\
\text { konsep }\end{array}$} & Jawaban kosong & 0 \\
\hline & $\begin{array}{l}\text { Tidak dapat mengembangkan syarat perlu dan syarat cukup } \\
\text { dari suatu konsep }\end{array}$ & 1 \\
\hline & $\begin{array}{l}\text { Dapat mengembangkan syarat perlu dan syarat cukup dari } \\
\text { suatu konsep tetapi masih banyak kesalahan }\end{array}$ & 2 \\
\hline & $\begin{array}{l}\text { Dapat mengembangkan syarat perlu dan syarat cukup dari } \\
\text { suatu konsep tetapi belum tepat }\end{array}$ & 3 \\
\hline & $\begin{array}{l}\text { Dapat mengembangkan syarat perlu dan syarat cukup dari } \\
\text { suatu konsep dengan tepat }\end{array}$ & 4 \\
\hline \multirow{5}{*}{$\begin{array}{l}\text { Menggunakan, memanfaatkan } \\
\text { dan memilih prosedur atau } \\
\text { operasi tertentu }\end{array}$} & Jawaban kosong & 0 \\
\hline & $\begin{array}{l}\text { Tidak dapat menggunakan memanfaatkan, dan memilih } \\
\text { prosedur atau operasi }\end{array}$ & 1 \\
\hline & $\begin{array}{l}\text { Dapat menggunakan memanfaatkan, dan memilih prosedur } \\
\text { atau operasi tetapi masih banyak kesalahan }\end{array}$ & 2 \\
\hline & $\begin{array}{l}\text { Dapat menggunakan, memanfaatkan, dan memilih prosedur } \\
\text { atau operasi tetapi belum tepat }\end{array}$ & 3 \\
\hline & $\begin{array}{l}\text { Dapat menggunakan memanfaatkan, dan memilih prosedur } \\
\text { atau operasi dengan tepat }\end{array}$ & 4 \\
\hline
\end{tabular}

Sumber : Adaptasi Kasum dalam jurnal Mawaddah (2016)

Hasil kemampuan pemahaman konsep matematika siswa dihitung dengan rumus:

$$
N=\frac{\text { skor yang diperoleh siswa }}{\text { skor total }} \times 100
$$

Nilai kemampuan pemahaman konsepadaptasi Ningsih (Mawaddah, 2016) yang diperoleh dari perhitungan kemudian dikategorikan sesuai dengan table berikut ini:

Tabel 4. Interpretasi Nilai Kemampuan Pemahaman Konsep

\begin{tabular}{ccc}
\hline No. & Nilai & Kriteria \\
\hline 1. & $85,00-100$ & Sangat Baik \\
2. & $70,00-84,99$ & Baik \\
3. & $55,00-69,99$ & Cukup \\
4. & $40,00-54,99$ & Rendah \\
5. & $0,00-39,99$ & Sangat Rendah \\
\hline
\end{tabular}

Sumber : Adaptasi Ningsih dalam jurnal Mawaddah 


\section{HASIL DAN PEMBAHASAN}

Tes diikuti oleh 22 orang dari kelas eksperimen dan 21 orang dari kelas kontrol. Dari hasil tes akhir dilakukan perhitungan, sehingga diperoleh nilai rata-rata, untuk kedua kelas sampel yang dinyatakan pada tabel hasil perhitungan data hasil tes pemahaman konsep matematika:

Tabel 5. Distribusi Hasil Tes Akhir

Pemahaman Konsep Matematika Siswa Kelas Sampel

\begin{tabular}{cccccc}
\hline Kelas & N & Nilai Maks & Nilai Min & $\overline{\boldsymbol{x}}$ & $\mathbf{S}$ \\
\hline Eksperimen & 22 & 100 & 46 & 81,61 & 15,52 \\
Kontrol & 21 & 100 & 33 & 72,40 & 18,51 \\
\hline
\end{tabular}

Dari data pada tabel 5 dapat dilihat bahwa dengan jumlah siswa 22 orang, rata-rata hasil tes pemahaman konsep matematika kelas eksperimen sebesar 81,61 sedangkan kelas kontrol dengan jumlah siswa 21 orang rata-ratanya sebesar 72,40. Nilai maksimum kelas eksperimen dan kelas kontrol adalah 100, sedangkan nilai minimum pada kelas eksperimen adalah 46 dan kelas kontrol adalah 36. Simpangan baku masing-masing dari kelas eksperimen dan kontrol berturutturut adalah 15,52 dan 18,51. Berdasarkan data tersebut dapat disimpulkan bahwa rata-rata hasil tes akhir pemahaman konsep matematika siswa kelas eksperimen lebih tinggi dari pada kelas kontrol.Adapun rekapitulasi hasil uji- $t$ pada kedua kelas sampel dapat dilihat pada tabel berikut:

Tabel 6. Hasil Perhitungan Uji Hipotesis

\begin{tabular}{ccccc} 
Kemampuan Pemahaman Konsep Matematika Siswa Kelas Sam \\
\cline { 2 - 5 } Kelas & $\mathbf{N}$ & $\overline{\mathbf{X}}$ & $\boldsymbol{t}_{\text {hitung }}$ & $\boldsymbol{t}_{\text {tabel }}$ \\
\hline Eksperimen & 22 & 81,61 & 1,77 & 1,68 \\
Kontrol & 21 & 71,40 & & \\
\hline
\end{tabular}

Pada tabel 6 diketahui bahwa $t_{\text {hitung }}$ sebesar 1,77 dan P-value sebesar 0,042. Sedangkan $t_{\text {tabel }}$ pada selang kepercayaan $95 \%$ untuk $\mathrm{N}-K=43-2=41$ sebesar 1,68. Berdasarkan perolehan tersebut dapat disimpulkan bahwa pada penelitian ini $H_{0}$ ditolak dan $H_{1}$ diterima karena $t_{\text {hitung }}>t_{\text {tabel }}$ dan $\mathrm{P}$-value $>\alpha$, yang artinya kemampuan pemahaman konsep matematika siswa yang mengikuti pembelajaran dengan model Learning Cycle $7 E$ lebih baik daripada pembelajaran konvensional di kelas XI IPS SMA N 1 Sungai Pua tahun pelajaran 2018/2019.

\section{KESIMPULAN}

Berdasarkan hasil penelitian yang telah dilakukan, dapat diambil kesimpulan sebagai berikut: "Kemampuan pemahaman konsep matematika siswa yang mengikuti pembelajaran dengan model Learning Cycle 7E lebih baik daripada pembelajaran konvensional di kelas XI IPS SMA N 1 Sungai Pua tahun pelajaran 2018/2019"

\section{REFERENSI}

Adilah, Dina Nur, dkk. (2015). Model Learning Cycle 7E dalam Pembelajaran IPA Terpadu, (Prosiding Seminar Nasional Fisika dan Pendidikan Fisika, ISSN: 2302-7827, Vol. 6 No. 1), diakses 12 April 2018.

Mawaddah, Siti, dkk. (2016). Kemampuan Pemahaman Konsep Matematis Siswa SMP dalam Pembelajaran Menggunakan Model Penemuan Terbimbing (Discovery Learning). FKIP Universitas Lambung Mangkurat, Vol. 4 No. 1, diakses 21 April 2018. 
Ngalimun. (2013). Strategi dan Model Pembelajaran. Yogyakarta: Aswaja Pressindo.

Permendikbud No. 58 Tahun 2014 Tentang Pedoman Mata Pelajaran Matematika. Jakarta.

Sadia, I Wayan. (2014). Model-Model Pembelajaran Sains Kontruktivistik. Yogyakarta: Graha Ilmu.

Shoimin, Aris. (2014). 68 Model Pembelajaran Inovatif dalam Kurikulum 2013. Yogyakarta: Ar-Ruzz Media.

Suryabrata, Sumadi. (2014). Metodologi Penelitian. Jakarta: PT. Raja Grafindo Persada. 